\title{
PRICES AND COUPONS FOR BREAKFAST CEREALS
}

\author{
Aviv Nevo \\ Catherine Wolfram \\ Working Paper 6932 \\ http://www.nber.org/papers/w6932 \\ NATIONAL BUREAU OF ECONOMIC RESEARCH \\ 1050 Massachusetts Avenue \\ Cambridge, MA 02138 \\ February 1999
}

\begin{abstract}
We are grateful to Angela Chien and Charles Vick for excellent data assistance and would like to thank Severin Borenstein, Richard Caves, Ken Chay, Ken Corts, Richard Schmalensee, and seminar participants at the Berkeley/Stanford IOFest, the NBER IO Summer Institute, Harvard University, UCLA, UCSD, University of Connecticut, and University of Maryland for useful comments and suggestions. The views expressed here are those of the author and do not reflect those of the National Bureau of Economic Research.

(0) 1999 by Aviv Nevo and Catherine Wolfram. All rights reserved. Short sections of text, not to exceed two paragraphs, may be quoted without explicit permission provided that full credit, including ${ }^{\circledR}$ notice, is given to the source.
\end{abstract}


Prices and Coupons for Breakfast Cereals

Aviv Nevo and Catherine Wolfram

NBER Working Paper No. 6932

February 1999

\begin{abstract}
This paper explores the relationship between shelf prices and manufacturers' coupons for 25 ready-to-eat breakfast cereals. Contrary to the predictions of static monopoly price discrimination, we find the shelf prices for a particular brand in a particular city are generally lower during periods when coupons are available. We find evidence that is also inconsistent with dynamic theories of pricing that predict lower prices and coupons after periods of low demand, and find little support for explanations of couponing based on the vertical relationship between manufacturers and retailers. We find some support for models of price discrimination in oligopoly settings that suggest interbrand competition can cause all prices to be lower than the uniform (non-discriminatory) price. We also find some evidence suggesting that firm-wide incentives may induce managers to use coupons and price cuts simultaneously in order, for example, to meet market share targets.
\end{abstract}

Aviv Nevo

University of California, Berkeley

549 Evans Hall \#3880

Berkeley, CA 94720-3880

and NBER

nevo@econ.berkeley.edu
Catherine Wolfram

Littauer 209

Harvard University

Cambridge, MA 02138

and NBER

cwolfram@harvard.edu 


\section{INTRODUCTION}

Economists have devoted substantial theoretical and empirical work to analyzing advertising decisions, while another predominant form of short-run non-price competition, promotions, has received almost no attention. According to a 1993 survey, the typical non-durable goods' manufacturer spent more money on promotions than on advertising. ${ }^{1}$ The costs of couponing are by far the largest component of promotion budgets. $^{2}$ In 1996, consumer packaged goods manufacturers distributed 268.5 billion coupons, of which 5.3 billion ( 2 percent) were redeemed. The average face value for coupons issued in 1996 was 67 cents, so consumers redeemed coupons worth approximately $\$ 3.5$ billion. $^{3}$

This paper considers coupons for ready-to-eat (RTE) breakfast cereals, one of the most heavily couponed products. ${ }^{4}$ The time spanned by our study includes a rapid escalation in couponing, and preceded attempts by some of the manufacturers to stop issuing coupons. We assess whether the relationship between coupons and shelf prices is consistent with the widely expressed view that coupons are primarily a tool to allow price discrimination. Finding that they are not, we exploit the richness of our data to document couponing patterns across brands and cities and over time. By supplying as many "stylized facts" as possible, we seek to provide insight on the empirical relevance of additional theories for why manufacturers use coupons.

\footnotetext{
${ }^{1}$ Donnelly Marketing Inc. $16^{\text {th }}$ Annual Survey of Promotional Practices reports that trade promotions accounted for 46.9 percent of the typical promotion budget, consumer promotions 27.9 percent and media advertising 25.2 percent. We will focus on consumer promotions, which are still larger than advertising.

${ }^{2}$ Manufacturers circulate coupons in newspapers, magazines or direct mailings. If a customer clips a coupon, brings it to a store and buys the designated product, he or she is entitled to a discount. Other forms of promotions include in-store displays or samples.

${ }^{3}$ These statistics were collected by NCH Promotional Services and reported in several publications, including Marketing News, March 31, 1997, p. 26.

${ }^{4}$ For example, in 1993 there were more coupons redeemed for breakfast cereals than any other group of consumer goods except "health and beauty aids" (see Brandweek, March 21, 1994, p.44).
} 
We draw on a three-dimensional panel data set with information on shelf prices and available coupons for $25 \mathrm{RTE}$ breakfast cereal products in up to 65 cities for every quarter from the beginning of 1989 until the end of 1992. We observe quarters during which there was no coupon for a particular brand in some cities and others in which a coupon was recently distributed and compare shelf prices under the two scenarios. The static monopoly price discrimination theory predicts a (weakly) positive correlation under a broad set of assumptions. Since coupon and price decisions are made simultaneously, it is necessary to control for common shocks to demand or costs that may affect both decisions. We do so by exploiting the panel nature of the data set.

We find that shelf prices are generally lower when there is a coupon available, and this result holds as we add a number of fixed effects to control for unobserved changes in demand and costs. Next we evaluate the patterns of coupons across brands, cities and time, to gather some suggestive evidence on a number of possible explanations for the negative relationship between coupons and shelf prices. We find some support for models of price discrimination in oligopoly settings that suggest inter-brand competition can cause all prices to be lower than the uniform (non-discriminatory) price (Corts, 1998). We also find some evidence suggesting that coupons are used most intensively at the end of manufacturers' fiscal years (and these differ across manufacturer). This suggests brand managers have incentives to use coupons and price cuts simultaneously in order, for example, to meet market share targets.

We find less support for theories that suggest the vertical relationship between manufacturers and retailers affects the correlation between shelf prices and coupons, and evidence that is inconsistent with dynamic descriptions of demand that predict that lower prices could accompany coupons.

Existing work on couponing was spawned by several disciplines, including economics and marketing. Some researchers, primarily economists, have chosen to explore the potential price discriminatory effects of coupons. The empirical work has uncovered patterns consistent with the price discrimination interpretation of coupons, showing for 
instance that coupon users have more elastic demand than non-users (see Narasimhan, 1984). No papers (of which we are aware) look directly at the relationship between shelf prices and coupons. ${ }^{5}$ Other researchers have addressed the promotional dimensions of couponing, and emphasize, for instance, the effects coupons have on the likelihood that a consumer will try a new product, or how coupons might shift the point in time when a consumer decides to purchase a product.

This paper also adds to the literature on the RTE breakfast cereal industry. The industry has attracted the attention of both academic economists and the antitrust authorities since it is a highly concentrated, stable oligopoly. Several dimensions of the industry have been analyzed, including product positioning (Schmalensee, 1978, and Scherer, 1979) and pricing (Nevo, 1998). Our paper provides a unique analysis of manufacturers' short-run, non-price strategies.

The rest of this paper proceeds as follows. In the next section, we review past work on coupons, organizing the summary into theories that predict that coupons and prices will be positively correlated and those that predict coupons and prices will be negatively correlated. In the third section we describe our data. Section four presents our empirical results and section five concludes.

\section{POTENTIAL RELATIONSHIPS BETWEEN COUPONS AND SHELF PRICES}

In this section, we summarize a number of theories of couponing, focusing on their implications for the relationship between coupons and shelf prices. We first describe explanations that predict coupons and prices will be positively correlated

\footnotetext{
${ }^{5}$ Of all the existing studies of which we are aware, Levedahl (1986) probably comes closest to ours. He uses individual transaction-level data to show that prices for paper towels are higher for transactions that involve coupons, controlling for brand and geographic area effects. He does not control for time effects over his 18-month sample, and couponing rates for most products have increased over time (as have prices), nor does he control for aspects of the individual transactions, such as the store at which the purchase was made. Also, his price variable does not reflect instore discounts (e.g. store coupons).
} 
(implying that prices will go up when coupons are available) and next focus on explanations that predict that coupons and prices will be negatively correlated. We also briefly outline the testable implications of each theory.

\section{Prices will Go Up When Coupons are Available}

\section{Static Monopoly Price Discrimination}

Couponing is a canonical example of price discrimination. ${ }^{6}$ A monopolist may profitably charge discriminatory prices if he can identify consumers with different elasticities and prevent the consumers who receive the lower price from reselling. If only more price-sensitive customers bother to clip, save and use coupons, they allow the manufacturers to separate customers into groups with distinct price elasticities. High transaction costs prevent resale.

Under some very general conditions on demand, the theoretical effect of thirddegree price discrimination on prices is unambiguous in the case of a monopolist. If a monopolist can separate its customers into two groups, it will charge the group with less elastic demand a higher price than the group with the more elastic demand. The less elastic group's price will also be (weakly) higher than the uniform price (see Varian, 1989 for an overview). ${ }^{7}$

A number of empirical studies have found indirect evidence suggesting that coupons allow sellers to price discriminate. Studies have demonstrated (1) that coupon users have higher price elasticities of demand (Narasimhan, 1984), (2) that low-priced generic products have lower market shares if the brand-name manufacturers coupon heavily (Sethuraman and Mittelstaedt, 1992), and (3) that a larger percent of consumers

\footnotetext{
${ }^{6}$ For example, both Pindyck and Rubinfeld (1995, p. 372) and Carlton and Perloff (1994, pp. 432-433) discuss coupons as examples of price discrimination.

${ }^{7}$ Varian (1985) and Schmalensee (1981) consider the welfare effects of third-degree price discrimination.
} 
use coupons for brands with higher shelf prices (Vilcassim and Wittink, 1987). All these studies address the question of whether manufacturers could use coupons to price discriminate. We, on the other hand, are interested in describing manufacturers' main motivations in issuing coupons.

Our approach circumvents some of the challenges faced by most empirical attempts to identify instances of price discrimination. For instance, different groups of consumers may be charged different prices if costs vary by group. For instance, we find that coupons are more frequently disseminated in large cities and that shelf prices are also higher in the large cities. Simply looking at cross-city differences, therefore, would suggest shelf prices and coupon availability are positively correlated. It is plausible, however, that delivery or retailer costs are higher in large cities while the cost of distributing coupons is lower (for instance, if there is a fixed cost that gets spread over more people). Within cities, the cost of supplying a box of cereal to coupon users and non-users is clearly identical. (If anything, the supplier incurs additional costs to circulate and process the coupons.) Existing empirical studies of price discrimination with coupons have generally relied on broad cross-sectional comparisons and have done little to account for other possible explanations of observed patterns. ${ }^{8}$

\section{Correlation between Coupons and Advertising Campaigns}

Absent cost differences, a positive correlation between coupons and shelf prices does not prove they are being used to price discriminate. Prices and coupons might be positively correlated if coupons are associated with factors that shift demand for a product at all prices. Many marketing articles consider the demand effects of coupons by assessing the types of customers that use coupons and how they affect consumers' purchase decisions. ${ }^{9}$ Though the literature tends not to speak directly to the relationship

\footnotetext{
${ }^{8}$ For instance, Gerstner, Hess and Holthauser (1994) compare the number of coupons issued by broad product category and relate it to retailers average margins by product category.

${ }^{9}$ The marketing literature on coupons is extremely broad, and we by no means purport to provide a comprehensive summary of it. For one thing, we deliberately focus on studies that have some implications for the relationship between shelf prices and coupons.
} 
between coupons and shelf prices, the results suggest that if coupons shift demand out prices and coupons may be positively correlated. Increases in demand will lead to higher prices if the suppliers face upward sloping cost functions or if demand becomes less elastic and suppliers raise markups.

Marketing articles have used a variety of techniques to assess whether coupons expand demand for a product (that is, generate incremental sales). For example, Neslin (1990) examines coupons for seven instant coffee brands over a one-year period in one (unnamed) city. He finds a positive correlation between coupon availability and a brand's market share and concludes that on average 44 percent of coupon users would not have purchased the brand in absence of a coupon. Chiang (1995), however, explicitly models individual consumers' decisions to use a coupon (to account for selection) and finds that coupons do not expand demand for a particular category of product, though he does not consider intra-category, inter-brand effects.

Other research has focused on whether characteristics of the coupon itself affect whether the coupon lures new or infrequent users (i.e., expands demand). Neslin and Clarke (1987) experimentally distributed coupons and then surveyed recipients on the frequency with which they purchased the product in the past and whether or not they used the coupon to purchase the good after they received it. They find, for instance, that when the survey respondents had to voluntarily request coupon booklets, they were more likely to use the coupons to try new brands. Similarly, Lee and Brown (1985) show that a particular type of coupon increased demand for non-coupon users while others only affected users' demand (see also, Srinivasan, Leone and Mulhern, 1995). Other studies have assessed whether characteristics of the advertisements accompanying a coupon in the free-standing inserts (FSIs) change redemption patterns (LeClerc and Little, 1997).

If coupons are used to price discriminate, one still might observe coupons generating incremental sales since price discrimination allows the supplier to price below the valuation of a larger number of customers. Other explanations suggest that coupons could shift demand by either alerting customers to the existence of a new good or 
reminding them of the attributes of an old one. Without surveying customers about their motivation for using a particular coupon, it is very difficult to distinguish between the two effects. (One could imagine trying to take advantage of the fact that the price discrimination theory suggests a relationship between shelf prices and the face value of the coupon while shifts in demand are likely to be independent of face value, though it still may be difficult to disentangle the effects.) For our purposes, we simply want to note that coupons may shift demand, so even if manufacturers don't use them to price discriminate, shelf prices may go up when coupons are available.

\section{Prices will Go Down When Coupons are Available}

\section{Price Discrimination with Strategic Interaction Effects}

Recent work has extended the theory of price discrimination to oligopolistic industries (see Katz, 1984; Borenstein, 1985; Holmes 1989; and Corts, 1998). Holmes (1989) shows that, under certain symmetry assumptions, the unambiguous prediction that discrimination will lead to higher profits extends to an oligopoly setting. Corts (1998), however, points out that Holmes' symmetry assumptions are not innocuous. He derives conditions under which price discrimination may lead to lower profits, and, more importantly for our purposes, to lower prices for all consumers.

Corts' logic is best demonstrated through a simple example. ${ }^{10}$ Suppose there are two types of cereal buyers, students and professors, and two types of cereal, Kellogg's Raisin Bran and General Mills Cheerios. At equal prices students prefer Cheerios, while professors happen to think Raisin Bran tastes better and are less price sensitive than students. Assume that both cereals are manufactured at zero marginal cost. Also suppose that students cut coupons and professors do not. Without coupons (i.e. if the sellers are constrained to charge uniform prices), there is a plausible set of assumptions under which the Cheerios price would be lower than the optimal price to students and higher than the

\footnotetext{
${ }^{10}$ This example is similar to the one presented by Corts in his section two.
} 
optimal price to professors, and the uniform Raisin Bran price would be higher than a student-only price and lower than a professor-only price.

Ignoring strategic responses to the other firm's prices for a minute, it is clear that Cheerios has no incentive to offer coupons, but Raisin Bran can profitably use coupons to try to set a lower price for students. If Raisin Bran issues a coupon, which given our assumptions is used solely by students, Cheerios will want to lower its price to students, which will result in a lower shelf price, and potentially a coupon, for Cheerios. If the Cheerios shelf price is lowered enough this will generate competition for Raisin Bran in the professors markets; thus, in turn generating a response from Raisin Bran. In the end, both Raisin Bran and Cheerios shelf prices may be lower with coupons.

There are several assumptions that this example embodies, but only one that is central to Corts' result. Prices will only fall for all consumers if the coupon users and non-users have different brand preferences. (In the example, professors preferred Raisin Bran and students preferred Cheerios.) Corts labels this condition "best-response asymmetry." The plausibility of this assumption to the RTE cereal market is unclear.

Empirically, we can assess the influence of strategic interaction effects by considering whether the relationship between a given brand's price and the coupons for that brand are influenced by the presence of coupons for competing brands.

\section{Dynamic Demand Effects}

Prices and coupons may be negatively correlated if the manufacturers' decision to issue a coupon is correlated with factors that change demand in a market. For instance, Sobel (1984) develops a model in which suppliers periodically discount goods to clear the market of low valuation consumers. The model he develops assumes two types of consumers - high valuation and low valuation. Sobel also assumes that consumers arrive in the market over time and that low valuation consumers are willing to postpone their purchases. He demonstrates that sellers will periodically find it optimal to lower prices to 
clear out low valuation consumers. An extension of his model might suggest that sellers periodically use coupons to clear out low valuation consumers and leave shelf prices unchanged at the high consumers' valuation. ${ }^{11}$ (Sellers may only use coupons periodically if there are costs to distributing and processing them.) If only low valuation consumers are willing to use coupons and there are only two types of consumers, this would predict zero correlation between shelf prices and coupons. A slight augmentation of Sobel's model might suggest that sellers periodically use both coupons and price reductions to clear out low and very low valuation consumers. (Note, however, that for some distributions of consumer types, periodic coupons could permit higher shelf prices.)

These models predict that coupons are issued in response to intertemporal patterns in demand - in this case the accumulation of low valuation consumers. Such changes in demand are difficult to measure empirically, though we attempt to corroborate these stories in several ways. For one, these stories predict distinct patterns in the relationship between the volume of cereal sold and coupons. Coupons would tend to be associated with high volume and may follow periods of low volume sales. Coupons are also unlikely to be issued in back-to-back periods.

There are also suggestions in the marketing literature that coupons affect the point at which people make a decision to buy a product. For instance, a consumer who sees a coupon in the Sunday paper may put the product on her shopping list and then be convinced to buy the product when she sees the product on sale at the store. Sellers may be willing to temporarily lower prices to lure new buyers if the new buyers, having tried the product, are willing to purchase the product in the future at the full price. (Levedahl, 1986 presents a model of coupons with dynamic effects on demand.) While these ideas often are difficult to reconcile with economists' notions of well-defined preferences, they suggest a negative correlation between prices and coupons.

\footnotetext{
${ }^{11}$ Various marketing studies lend some support to the hypothesis that coupons are used to target consumers that are willing to substitute demand intertemporally. Nesline, Henderson and Quelch (1985) find that coupons encourage people to accelerate their purchases and Eppen and Lieberman (1984) find that discounts encourage consumers to stockpile goods.
} 


\section{Retailers' Objective Functions}

To this point, we have abstracted from the fact that most goods for which coupons are issued are sold to the final consumers by a retailer and not by the manufacturer. (This is clearly the case for breakfast cereals). While the manufacturers issue coupons and set wholesale prices, retailers set the shelf prices. If coupons are simply price discriminatory mechanisms, it is relatively straightforward to show that the shelf price will increase (in the absence of the strategic effects discussed above). Even if the retail sector is perfectly competitive, manufacturers will increase the wholesale price. If retailers have some market power, they will increase the price further. Since all supermarkets provide baskets of goods, however, it is possible that the supermarkets take advantage of the advertising effects of coupons. If the coupons inspire customers to put a good on their shopping lists, supermarkets may then discount the couponed good (and advertise the discount) to lure people into their store, anticipating that they will also purchase high margin products. This effect might occur for cereal in particular since it is a staple good that a large fraction of consumers are likely to buy on a trip to a grocery store. Empirically we examine this hypothesis by correlating the patterns of coupons with structure of the retail sector in different cities.

\section{Retailer or Manufacturer Costs}

It is possible that the manufacturers and/or the retailers face declining average costs over some range. For instance, there could be economies of scale at the manufacturing level, or managing fluctuating inventory levels may be costly to either the retailer or manufacturer. In periods when demand is low (for instance, due to seasonal effects), manufacturers may simultaneously issue coupons and reduce prices. Also, within the cereal-manufacturing firms, the people making decisions about pricing and coupons may face incentives to sustain or increase market share or volume sales. For instance, brand managers may have market share goals they are trying to meet within a certain time frame. The cheapest way for the brand managers to increase sales might well be to offer discounts to everyone, but bigger discounts through coupons to some 
people. $^{12}$

\section{DATA}

We explore the empirical relationship between coupons and shelf prices using data from two main sources. The cereal price data were obtained from the IRI Infoscan Data Base at the University of Connecticut. ${ }^{13}$ These data were collected by Information Resources, Inc. (IRI), a marketing firm in Chicago, using scanning devices in a national random sample of supermarkets in metropolitan areas and rural towns. Weekly data for UPC-coded products are drawn from a sample, which represents the universe of supermarkets with annual sales of more than $\$ 2$ million dollars, accounting for $82 \%$ of grocery sales in the US. In most cities the sample covers more than $20 \%$ of the relevant population, and due to the importance of the sample to its customers, IRI makes an effort to make the sample representative. This is confirmed by unpublished analysis conducted by the BLS.

In the Infoscan Data Base the data are aggregated by brand (for example different size boxes are considered one brand), city $^{14}$ and quarter. The data covers up to 65 different cities (the exact number increases over time), and ranges from the first quarter of 1989 to the last quarter of 1992. The price variable was created by dividing the dollar sales by the number of pounds sold. Dollar sales reflect the price paid by consumers at the cashier excluding discounts to manufacturer coupons. Therefore, the resulting variable is the city-brand-quarter average pre-coupon transaction price per pound.

\footnotetext{
${ }^{12}$ We distinguish this explanation from the intertemporal price discrimination story because agency relationships in the firm may make it optimal for brand managers to lower prices and issue coupons to meet market share goals, even if such decisions are not profit maximizing from the firm's perspective. We hypothesize that managerial incentives to issue coupons may have nothing to do with past or even current demand, unlike the intertemporal price discrimination explanation.

${ }^{13}$ We are grateful to Ronald Cotterill, the director of the Food Marketing Center at the University of Connecticut, for making these data available.

${ }^{14}$ Most of IRI's definition of cities are similar, but not identical, to MSA's.
} 
The coupon data were obtained from Promotion Information Management (PIM), a research company that tracks coupons and other promotional strategies. (For example, General Mills might hire PIM to keep track of Kellogg's couponing and vice-versa.) PIM collects data on coupons issued in 69 major metropolitan areas, including all 65 of the IRI areas. ${ }^{15}$ For each region, PIM obtains information on coupon inserts in the local newspapers (FSIs), on coupons run in the newspapers themselves (run-of-press) and on coupons in magazines. PIM also hires local residents to attempt to get on mailing lists to receive direct mailings, often containing coupons. Where they overlap, the PIM regions are closely aligned with IRI's geographic markets. Since most coupons are issued through inserts in newspapers, however, PIM's markets are defined by the circulation of the local newspaper and not strictly by the counties covered, as are IRI's markets. As a result, we may have some measurement error, to the extent people in, for instance, Hartford, Connecticut buy the Boston Globe instead of the Hartford Courant. We believe, however, that these measurement problems are limited.

We obtained information from PIM on coupons issued for every brand produced by the top five cereal manufacturers from 1989 through $1992 .^{16}$ The information consisted of the face value of the coupon, the cities where it was distributed, the distributor, date on which it appeared and its expiration date. The description of the coupons also characterizes the requirements that must be met for the customer to redeem the coupon, indicating, for instance, if the customer needed to buy two boxes of cereal to get a discount, or send in proofs-of-purchase labels to get a rebate. (The Appendix contains a more detailed description of the PIM data.)

\footnotetext{
${ }^{15}$ The additional metropolitan areas covered by PIM are Greenville, SC, Charleston, WV, Quad Cities and Tulsa, OK. PIM also covers Richmond and Norfolk, VA separately, though for purposes of comparison with the IRI data, we aggregate across the two cities.

${ }^{16}$ The top five producers during this time period were Kellogg, General Mills, Post, Quaker Oats and Nabisco.
} 
We matched the price and coupon data by city, brand and quarter. If a coupon spanned more than one quarter (for instance, if it was distributed in mid-February but did not expire until the end of December) we assigned the coupon to the quarter in which it was first issued. Previous research has found that about 60 percent of coupons are used in the first two months after they are issued (Bowman, 1980). Altogether, we have 23,350 observations reflecting information on 25 brands of cereal over sixteen quarters from 51 to 65 cities. (Over the time period we are considering, IRI's coverage expanded, so that at the beginning of the sample, we only have information for 51 cities and by 1992, we have information from 65.)

\section{EMPIRICAL ESTIMATES OF THE RELATIONSHIP BETWEEN PRICES AND COUPONS}

\section{Correlation Between Prices and Coupons}

Empirically, we model the relationship between prices and coupons with the following equation:

$$
\text { SHELF PRICE } E_{b c t}=\gamma_{b(c)}+\phi_{c(t)}+\delta_{t(b)}+\text { DOLLARS OFF } F_{b c t}+\varepsilon_{b c t}
$$

where SHELF PRICE $E_{b c t}$ is the average shelf price for cereal brand $b$ in city $c$ during quarter $t$ and DOLLARS OFF $F_{b c t}$ is the value of the coupon available for cereal brand $b$ in city $c$ during quarter $t .^{17}$ DOLLARS OFF $b c t$ takes on a value of zero when there is no coupon available. We also estimate versions of equation 1 which include COUPON $D U M M Y_{b c t}$, which equals one when there is a coupon available and zero when there is not, instead of DOLLARS OFF $F_{b c t} \cdot \gamma_{b}$ and $\phi_{c}$ capture brand- and city-specific factors that affect demand or the cost of selling cereal. $\delta_{t}$ is included to capture the trend in cereal

\footnotetext{
${ }^{17}$ Note that we are assuming that coupons are only valid in the cities where they are distributed. In fact that is not true, but we assume that there is limited transfer of coupons from one city to another.
} 
prices over the time period we consider. We also present estimates which allow the brand-fixed effects to vary by city (we estimate $\gamma_{b c}$ ), the city-fixed effects to vary across quarters (we estimate $\phi_{c t}$ ) and the quarter effects to vary by brand (we estimate $\delta_{b t}$ ).

Table 1 summarizes the variables we analyze. The average shelf price in our sample is about three dollars per pound. The bulk of the variation in shelf prices is across brands. The average discount offered through coupons is about 50 cents, and they are available in 85 percent of the observations we consider, though as we discuss in the Appendix, we suspect that the mean of this variable is high. ${ }^{18,19}$ The average face value of available coupons (i.e. the conditional mean) is about 55 cents. We note the difference between the breakdown in the variation of shelf prices and dollars off. While the variation in prices is largely explained by brand, city and quarter dummy variables, this is not the case with coupons. We shall return to this point below when we discuss the explanatory power of our results.

Before we present the results, it is useful to consider how our empirical specification identifies the relationship between prices and coupons. Ideally, we would like to have exogenous, or randomly assigned, variation in the distribution of coupons. If that were the case, we could identify the causal effect of couponing by comparing, for example, the price of a brand in a certain city where a coupon was issued to the price of the same brand in other similar cities where no coupons were issued. Unfortunately, it is very unlikely that coupons were issued (or "dropped") at random. Alternatively, we could assume that coupons were issued at random conditional on observable variables. For example, one could assume that for a given brand in a particular city the exact timing

\footnotetext{
${ }^{18}$ One problem we had to deal with when defining the data was that some of the coupons were not attributed to individual cities but rather were defined as national coupons with a percent coverage offered. We examined several assumptions, described in the Appendix, about how to attribute these coupons to cities. In general, our results are robust to a number of different assumptions.

${ }^{19}$ If more than one coupon was available, we took the mean value of the offered discounts. Very similar results obtain if we instead use the total value of all outstanding coupons or the maximum value.
} 
of the coupon is random. Using the richness of our data we are able to explore a variety of such assumptions.

Table 2 presents a number of estimates of Equation 1. Each column reports coefficients from separate specifications that use either DOLLARS OFF or COUPON $D U M M Y$ as the independent variable. Both specifications in a column include the same fixed effects. Moving across the columns, the specifications include increasingly more fixed-effects - the specifications in column I do not include any fixed effects while the specifications in column VIII include city-brand effects $\left(\gamma_{b c}\right)$, city-quarter effects $\left(\phi_{c t}\right)$ and brand-quarter effects $\left(\delta_{b t}\right)$. Taken together, the results provide a description of the relationship between coupons and prices within and between cities, brands and quarters.

The specification in column I provides an estimate of the average effect of coupons on prices assuming that the couponing decision is determined at random. For obvious reasons, that is probably not a reasonable assumption. Columns II through VIII add more fixed effects to the model, and by doing so change the nature of the experiment. For example, adding quarter fixed effects controls for an increase in the tendency to issue coupons but still assumes that in a given quarter the coupons are issued at random across cities and brands. Adding city fixed effects (column III) allows for a correlation within a city, but assumes that this correlation is fixed across brands.

Except for the coefficient on COUPON DUMMY in columns I through III, the results through column VII suggest that shelf prices are negatively correlated with coupons. $^{20}$ The negative relationship between prices and COUPON DUMMY is statistically insignificant in Columns VI and VII. Column VIII uses the most flexible definition of fixed effects allowable in our data set, and the results in that column suggest essentially no relationship between prices and coupons. 93 percent of the variance in the dependent variable, however, is explained simply by including the brand, city and quarter

\footnotetext{
${ }^{20}$ The Appendix discusses several tests we performed to assess the possibility that the negative correlation between prices and coupons is a result of the way our data are aggregated across box size, weeks within a quarter and stores within a city.
} 
dummy variables and 98 percent is explained by the time we add all the fixed effects (there are nearly $25 * 65+25 * 16+65 * 16=3065$ estimated in total) in Column VIII.

Comparing the results across columns provides evidence on the relationship between prices and coupons across cities, brands, and quarters. Prices and couponing (captured by both the number of coupons dropped, COUPON DUMMY, and discounts offered through coupons, DOLLARS OFF) were both increasing over the time period covered by our data set, so not surprisingly, controlling for quarter fixed effects in Column II dampens the positive relationship between the two variables. Coupons and prices are positively correlated across cities implying that there is more couponing in more expensive cities. (Between estimates yield a coefficient of .33 on COUPON $D U M M Y$, but the relationship is also discernible from the difference between columns II and III). Prices and coupon discounts are negatively correlated across brands, implying that higher valued coupons are issued for less expensive brands. The effect is the opposite for COUPON DUMMY, and fewer coupons are issued for the less expensive brands. (Neither of these effects is terribly strong in the between estimates.)

Slightly different patterns emerge when we estimate more flexible fixed effects. Generally, the between city-brand effects are negative for DOLLARS OFF and positive for COUPON DUMMY (column II vs. column V). This suggests that there are higher valued coupons for cereals that are priced below the city average cereal price, but fewer of them. The between brand-quarter effects are positive, suggesting that there are more coupons for brands that sell for more of a premium in a particular quarter than the simple average quarter price suggests. The between city-quarter effects are positive, suggesting that there are more coupons in cities with more inflation.

If the fixed effects that we add in the later columns of Table 2 are correlated with the independent variables (either DOLLARS OFF or COUPON DUMMY), the results in the earlier column that did not include these fixed effects are suspect. We can obtain a measure of the bias reflected in the coefficients reported in the early columns of Table 2 by comparing the fixed-effect results to random-effects specifications. A random-effects 
specification assumes that the excluded effects are uncorrelated with the independent variables so that a regression without these effects will yield consistent but inefficient estimates, as will a fixed-effects estimator. If, on the other hand, the excluded effects are correlated with the couponing measure than a random-effects estimator will be biased. This has been widely used to construct a Hausman test for the null that the effects are not systematically correlated with the independent variables (Hausman, 1978).

We performed Hausman tests on six sets of fixed effects: city, quarter, brand, city-brand, city-quarter and brand-quarter. In all cases save one, the data does not reject the equality of the random effects and fixed effects estimators, suggesting that the changes in the estimated values of the coefficients between the different columns of Table 2 are not due to correlation between unobserved effects and the couponing measure. The one case where the Hausman test rejected the null was for city-brand effects. This suggests that only those columns in Table 2 that include the interacted citybrand dummies are unbiased. The Hausman tests also provide us with some guidance in interpreting the additional explanations for coupons, suggesting that explanations that predict systematic differences in couponing practices for brands by city are more valid than explanations, that, for instance, predict systematic differences for brand over time. For instance, if coupons are being used to stave off generic competition, we might expect them to be correlated with brand-specific price increases over time. That is not the case. Instead, if coupons are issued as a strategic response to a competitor's coupon strategy in a particular city, we would expect them to be correlated with city-brand effects.

In general, the effect suggested by the results is small. The largest coefficient on DOLLARS OFF (column III) suggests that the shelf price decreases by ten cents (less than three percent of both the average price and the standard deviation in price) when a coupon for 55 cents (the average coupon size in our data) is introduced. However, it is likely that due to the aggregation of the data, the independent variable is measured with some error, suggesting the coefficients are biased downward. It is well known that this bias is augmented by the use of within estimators. Following Griliches and Hausman (1986) we are able to use the panel structure of our data to both test for measurement 
error and also correct the bias. For example, first-difference estimation of the coefficient on DOLLARS OFF in column V of Table 2 yields a coefficient of -.02, while an eight quarter difference estimator yields a coefficient of -.09. This pattern is consistent with the existence of measurement error. Using a partial implementation of the GrilichesHausman method to correct for this bias we obtain a coefficient of -.22 . We conclude that the effects are not as small as they might seem.

Taken together, the results in Table 2 suggest that coupons do not have a positive effect on prices, at least for the brands, years and cities our data cover. If one is willing to accept that the fixed effects control for all potential endogeneity problems, then these results suggest that manufacturers do not view coupons primarily as price discriminatory mechanisms, at least as predicted by static models of monopoly price discrimination. However, it is possible that even in the most unrestricted specification there is still a systematic component in the error term that is correlated with the couponing decision. Given the extremely high $R^{2}$ that seems unlikely, though it is still a possibility. Even if the results presented in Table 2 do not fully rule out this possibility they strongly suggest that coupons are not merely a tool that allow firms to price discriminate. Rather there are additional factors that are jointly influencing pricing and couponing decisions, and the effects of these factors seem to dominate the effects of price discrimination.

In order to shed light on some of the possible factors influencing couponing and pricing, the remainder of this section documents a number of patterns across brands, across cities and over time, the very effects Table 2 controls for. While we attempt to organize the discussion of the facts around certain possible explanations for the results in Table 2, we also simply intend to document the trends and leave formulation and testing of specific hypotheses for future research.

Cross-Brand Effects 
Table 3 describes coupon issues by type of cereal and by manufacturer. ${ }^{21,22}$ Across manufacturers, there seems to be a relationship between size and couponing. The manufacturers are arranged from left to right in order of their market share within the industry, and the number of coupons per brand decreases almost monotonically across the bottom row of Table 3. (Kellogg offers more coupons with restrictions than General Mills, so when we include restricted coupons in Table 3, Kellogg issues more per brand than General Mills.) The manufacturer effects primarily drive differences by type of cereal, although most manufacturers coupon less heavily in the "Kids" category.

Table 4 describes the patterns in coupon issues over time, documenting a significant increase in the number of coupons issued over the time period we consider. There were nearly 60 percent more coupons issued in 1992 than in 1989. Surveys of coupon practices across all consumer goods manufacturers also document increases between 1989 and 1992, though not quite as dramatic as for cereals. No distinct pattern in couponing across quarters holds during all four years.

One possible explanation for the negative relationship between coupons and prices is that the manufacturers facing particularly intense competition from generic manufacturers are both couponing heavily and reducing prices. ${ }^{23}$ To evaluate that hypothesis, we obtained additional data on sales of generic products (see Wongtrakool, 1994), including information on the market shares of the ten leading generic brands in 1991 and 1992. Two of these generic products compete directly with cereals that are not in our sample (apple cinnamon toasted oats and bran flakes), but the rest provide competition for nine of the brands in our sample. ${ }^{24}$ While brands with heavy generic

\footnotetext{
${ }^{21}$ Table A1 in the Appendix lists the brands in our sample by segment.

${ }^{22}$ Note that the data in Tables 3 and 4 represent the total number of coupon issues, including issues for the same brand in the same quarter and city.

${ }^{23}$ Note, however, that the fact that the relationship between prices and coupons is positive between brand-quarters is inconsistent with this hypothesis.

${ }^{24}$ The brands facing strong generic competition are: Cheerios, Corn Flakes, Frosted Flakes, Rice Crispies, Raisin Bran (both Kellogg and Post), Lucky Charms, Froot Loops and Honey Nut Cheerios.
} 
competition tended to coupon more, brands that do not face heavy generic competition showed higher increases in the number of coupons dropped over the time period we consider. Also, couponing practices within the brands facing strong generic competition was negatively correlated with increases in generic sales.

It is also possible that the promotion activities of other branded manufacturers influence the competitive environment within which couponing decisions are made. As discussed in section two, price discrimination in an oligopoly setting can, under certain assumptions, cause all prices to fall. Essentially, if prices are strategic complements and consumers have heterogeneous preferences over cereals, a rival's coupon may cause a seller to issue a coupon and lower its shelf price. To evaluate that description of our data, we estimated specifications similar to those reported in Table 2, and included an interaction between COUPON DUMMY and a variable indicating whether or not competitors had valid coupons for "similar" products. ${ }^{25}$ The results are reported in Table 5.

The results are sensitive to the presence of fixed-effects, and more so than the results in Table 2. The interaction term is positive until we introduce brand effects, and then it is negative and significant in specifications IV through VII. ${ }^{26}$ The negative coefficient on the interaction term supports the hypothesis that coupons are more likely to accompany price reductions when they are contemporaneous with a competitor's coupon. This suggests that coupons introduced independently of competitors' have the effect on prices predicted by theories of monopoly price discrimination. The confounding effects of monopolistic and oligopolistic price discrimination may explain the results in Table 2. It is also interesting to note that the coefficient on COMPETITORS COUPON becomes

\footnotetext{
25 "Similar" products are defined as cereals classified in the same row of Table 3. COMPETITORS' COUPON is equal to mean of COUPON DUMMY across competing manufacturers' brands in the same product category during the same quarter in the same city. The mean of the variable across all observations is .85 . The mean of the interaction between COMPETITORS' COUPON and COUPON DUMMY is .73.

${ }^{26}$ The importance of the brand effects suggests that the manufacturers are offering competing coupons more often for more expensive brands.
} 
positive. This is consistent with a model in which a competitor's coupon lures the lower valuation, and more price-sensitive, consumers thus increasing the optimal price for the remaining customers.

While the interpretation we offer in the previous paragraph is intriguing, we offer it with some trepidation. First, the product categories are admittedly somewhat ad hoc, although the coefficients on the interaction terms are insensitive to small changes in the categories. Second, it is possible that the coefficient on the interaction term is picking up an omitted variable that influences all manufacturers' decisions to coupon. Such an effect is harder to reconcile with the results that include extensive fixed effects, so we have more confidence in the results at the bottom of Table 5. Third, looking at the simple correlation in couponing activity by city-quarter, we find more correlation across brands within a manufacturer than across manufacturers within segments. For example, the correlation between the mean of COUPON DUMMY for a given city-quarter for Kellogg and General Mills in the All Family category is .21, while the correlation between the mean of COUPON DUMMY for Kellogg All Family and Kellogg's TasteEnhanced/Wholesome is .60. Similarly, Kellogg's Raisin Bran is much more likely to have a coupon in a given city at the same time as Kellogg's Froot Loops than at the same time as Post Raisin Bran.

We also considered patterns in each manufacturer's couponing activity over time. In conversations with us, brand managers for several consumer products indicated that coupons are often used to provide short-term boosts in market share, in order, for instance, to meet goals set by the firm. To confirm this, we considered patterns in couponing approaching the end of each company's fiscal year. Conveniently, the five companies in our sample have fiscal years that end in three different months. ${ }^{27}$ Fiscalyear end effects were most evident for General Mills and Kellogg, as Kellogg issued 15 percent more coupons in the last quarter than in any other quarter, and General Mills

\footnotetext{
${ }^{27}$ Kellogg, Post (a subsidiary of the Philip Morris Companies) and Nabisco (a subsidiary of RJR Nabisco) all have fiscal years ending in December. General Mills' fiscal year ends in May, and Quaker's fiscal year ends in June.
} 
issued from 10 to 15 percent more in the first and second quarters. Post is most active in the fourth quarter before its December fiscal year end, although the increase over other quarters is not substantial. Fiscal year end effects were not evident for Quaker and Nabisco, but perhaps that is because we observe coupons for so few of their brands. We observe similar patterns in advertising (and, generally, advertising expenditures and couponing are positively correlated) contributing to the view that manufacturers are using coupons, and other promotional devices, for short-run sales boosts.

\section{Cross-City Effects}

Coupons and prices are positively correlated across cities. A number of exogenous factors that vary across cities (for instance, population density and per capita income) may explain that result. The organization of the retail grocery sector also varies across cities and plausibly can give us some insight into our results relating coupons to prices.

Table 6 documents coupon issues in several cities, and demonstrates considerable heterogeneity in couponing across them. The first column lists the total number of coupons issued in a particular city over the time period we study. The middle column lists the average discount offered per coupon in dollars. The last column lists the sum of the discounts offered divided by the total number of quarters covered by our data (16). This number represents the total savings a consumer could have achieved per quarter had they used every coupon issued in that city. The differences are considerable, and residents in Dallas were exposed to about 33 percent more coupons than were residents of Little Rock. The low number of coupons for Boston is somewhat misleading because Boston received more coupons with restrictions than unrestricted coupons, and is actually one of the most heavily couponed cities when we include restricted coupons.

Table 7 analyzes the relationship between several city-level variables and both the percent of brand-quarters during which a coupon was available in a given city (columns I, 
II and III) and the average price for cereal across the 25 brands (column IV). ${ }^{28}$ In column I, COUPON DUMMY is only positive if there is an unrestricted coupon available, while columns II and III consider patterns in all types of coupons. Column III considers the sub-sample of cities for which we have price data over all four years. All sets of regressions include region fixed-effects, although the coefficients on the other variables are essentially unchanged if we omit these. ${ }^{29}$

The first two variables, \% SUPERMARKETS and GROCERY CR4, measuring broad differences in the organization of the retail sector, are never significant in any of the specifications. ${ }^{30}$ The absence of a relationship between couponing and the retail market structure casts doubt on explanations, such as the one discussed in section 2, that competition among the retailers affects pricing responses to coupons.

We included STORES DOUBLING because managers suggested to us that they were more likely to coupon in cities where the local stores were willing to take steps to ensure that promotions successfully increased market share. Confirming this, the variable is positively correlated with the total number of coupons (restricted plus unrestricted) a city receives, although it is negatively correlated with the number of unrestricted coupons cities receive. Most restricted coupons (e.g. buy one get one free) are not doubled, so it is possible that DOUBLING proxies for other steps local stores will take to push brands, and manufacturers avoid inflicting the direct costs of unrestricted coupons on those stores.

Doubling is also positively correlated with prices. This could suggest that there is a causal relationship between the level of couponing activity and prices, consistent with

\footnotetext{
${ }^{28}$ The city-level variables are described in the Appendix.

${ }^{29}$ We will not discuss the coefficients on the last six variables in Table 7, which we included as controls for city demographic characteristics. We include \% HISPANIC because several marketing articles suggest that Hispanic-Americans are less likely to use coupons than AngloAmericans (see, e.g., Green, 1997).

${ }^{30}$ The lack of correlation is not due to collinearity between the retail market structure and other city-level attributes, because the variables are not significant in univariate specifications.
} 
discriminatory pricing across cities. Other variables, however, that are plausibly exogenous to pricing are positively correlated with couponing but not with price. We included NEWSPAPER DUOPOLY as a proxy for the costs associated with running advertisements with coupons in the local papers. Confirming this interpretation, it is positively correlated with the total number of coupons issued per city. There is very little relationship between the newspaper variable and prices. ${ }^{31}$

\section{Dynamic Effects}

We next investigate the dynamic effects of couponing. We examine two separate, but related, questions. First, we consider whether a decision to coupon is a function of previous quantities sold. Next, we look at the relationship between quantity sold and previous coupons offered. Since our goal is primarily to describe the dynamic relations between the endogenous variables we employ a panel vector auto-regressive (VAR) model and try to impose as little structure on the data as possible.

Let the dynamic relations between discounts offered by a coupon, shelf price and quantities sold, be described by the (structural) VAR model

$$
B_{0} Y_{b c t}=K+\sum_{l=1}^{m} B_{l} Y_{b c, t-l}+\gamma^{*}{ }_{b c}+\gamma^{*}{ }_{t}+u_{b c t}
$$

where

$$
Y_{b c t}=\left[\begin{array}{c}
\text { COUPON DUMMY } \\
\text { SHELF PRICE } \\
\text { VOLUME } \\
b c t
\end{array}\right]
$$

and $u_{b c t}$ is white noise with a diagonal variance matrix, $V$. This system consists of a couponing equation, a pricing equation and a demand equation. Assuming $B_{0}^{-1}$ exists we can re-write the structural VAR, given in equation 2, as a reduced form VAR, given by

\footnotetext{
${ }^{31}$ We estimated a specification similar to column IV of Table 7, which included COUPON $D U M M Y$ as an independent variable and instrumented for it with NEWSPAPER DUOPOLY. The coefficient on COUPON DUMMY was positive but not statistically distinguishable from zero.
} 


$$
Y_{b c t}=C+\sum_{l=1}^{m} \Phi_{l} Y_{b c, t-l}+\gamma_{b c}+\gamma_{t}+\varepsilon_{b c t}
$$

where

$$
C=B_{0}^{-1} K, \quad \Phi_{l}=B_{0}^{-1} B_{l}, \quad E\left(\varepsilon_{t} \varepsilon_{\tau}\right)=\left\{\begin{array}{cc}
\Omega=B_{0}^{-1} V & \text { if } t=\tau \\
0 & \text { otherwise }
\end{array}\right\} .
$$

Note that in the reduced form the contemporaneous effects of the endogenous variables are absorbed in the variance matrix of the errors.

Without the city-brand specific effects equation 3 can be estimated using OLS. Once the equation includes city-brand effects OLS no longer yields consistent estimates. Furthermore, it is well known that simply adding city-brand specific dummy variables to the estimated equations will not solve the problem (for a discussion see Chamberlain, 1983). Below we follow Holtz-Eakin, Newey and Rosen (1988) by first differencing the data and using past levels of the variables as instrumental variables.

The results are presented in Table 8. The first three columns in the table present the results for each of the endogenous variables, allowing for four lags in each of the variables, city-brand effects and quarterly dummy variables. The last three columns present the results for the same three equations without allowing for the city-brand or quarter effects.

The results in the column I through III of Table 8 suggest that coupons and prices Granger-cause volume but not vice versa. Prices and coupons, on the other hand, seem to impact each other with some lag. An interesting relation is suggested by the coefficients in column III. All lags of both the COUPON DUMMY and SHELF PRICE are correlated with current volume. However, the effect of price is decreasing over time, so longer lags are of smaller economic significance, while for coupons the effect is roughly constant. The signs of the coefficients suggest that a price decrease embodied in a coupon has the opposite effect of a reduction in the shelf price. Everything else constant, lower past shelf prices imply lower current demand, a result that is generally consistent with the Sobel (1984) theory of timing of sales. A past discount offered by a coupon has the 
opposite effect on volume, supporting one general theme of our results: coupons are not merely price cuts.

Before we discuss how these results shed light on the dynamic theories discussed in section two, we note a few more results. First, the OLS regression presented in column IV has a low R-squared compared to the values in columns V and VI. This is typical of our results: a smaller proportion of the variance in the coupon variable is explained by the model. Second, all of the qualitative results discussed here are the same if we replace the COUPON DUMMY variable with DOLLARS OFF.

In order to discuss the economic interpretation of the results we examine the MA(4) representation of the VAR model which is given by

$$
Y_{t}=\varepsilon_{t}+\Psi_{1} \varepsilon_{t-1}+\Psi_{2} \varepsilon_{t-2}+\ldots=\sum_{l=o}^{\infty} \Psi_{l} \varepsilon_{t-l}
$$

The matrix $\Psi_{l}$ measures the effect of a shock to $\varepsilon_{t-l}$ on the rest of the system holding everything else constant, i.e., $\Psi_{l}=\partial y_{t+l} / \partial \varepsilon_{t}{ }^{\prime}$. A plot of the $\Psi_{l}$ over $l$ is called the impulse response function and it captures all the information on how the shocks $\varepsilon_{t-l}$ affect the evolution of the endogenous variables in system described by equation 3 . The matrices $\Psi_{l}$ can easily be computed recursively from the estimates of the reduced-form VAR (see Hamilton, 1994).

The impulse response function based on equation 4 ignores the correlation between the shocks in the various equations, since it measures the effect of one shock holding everything else fixed. We recall that the correlation in these errors was introduced when we switched from the structural VAR model, given in equation 2 , to the reduced-form VAR, given by equation 3. Therefore, a different question to ask is what the effect of a shock to the (orthogonal) structural error on the endogenous variables would be? In order to answer that question we need to recover the structural parameters, in particular the contemporaneous effects captured by $B_{0}$. Without additional assumptions these effects cannot be identified. We explored several sets of 
assumptions $^{32}$ and use them to construct orthogonal impulse response functions. Since the variance matrix of the residuals, presented in the bottom of Table 8 , is nearly diagonal the results were nearly identical to those presented below and therefore are not discussed here. In all cases the structural parameter on COUPON DUMMY in the pricing equation was nearly identical to those presented in Table 2. Figure 1 displays various impulse response functions. Each graph displays the effects of a one standard deviation positive shock to the various error terms on the three different variables.

The results in Table 8 clearly suggest that manufacturers' decisions to coupon are not a function of previous quantities sold. Lagged values of quantity do not increase either the likelihood of introducing a coupon or the face value of the coupon. Section two also discussed two theories of the dynamic effects on demand. The first was in the spirit of Sobel (1984). This theory suggests a path-dependence in the impact of price cuts. Everything else equal, fewer price cuts (whether in the form of lower prices or in the form of discounts) in the past lead to higher current demand. The impact of lagged prices on volume is consist with this theory - all else equal, lower lagged prices decrease current demand. Also the negative correlation in the coupon variable is consistent with this theory. However, this theory is not consistent with the estimated effects of lagged coupons on volume. This does seem to suggest that this theory of the dynamic effects of coupons is not consistent with the data.

The final dynamic effect discussed in section two was an advertising effect. Coupons may induce consumers to try new brands, making them more likely to purchase the product in the future. Both the facts that coupons have a different impact than price cuts, and that their impact is somewhat long lasting are consistent with this theory. This

\footnotetext{
${ }^{32}$ The first assumption we used was to restrict the VAR model given in equation 2 to be recursive, which implies that the matrix $B_{0}$ is lower triangular and therefore uniquely determined by the Cholesky decomposition of the variance matrix of the residuals. We ordered the variables so that DOLLARS OFF at time $t$ is not impacted by the value of either SHELF PRICE or VOLUME at time $t$, SHELF PRICE is only a function of DOLLARS OFF, while VOLUME is a function of both the other variables. We also explored sign restrictions on the various coefficients. These assumptions were not sufficient to identify the parameters, however, they allowed us to bound the admissible parameter space. The bounds were tight.
} 
is by no means a conclusive proof of the theory, but our results suggest it is worthy of further investigation. ${ }^{33}$

\section{CONCLUDING COMMENTS}

This paper documents the patterns of prices and coupons in the RTE cereal industry. Both the negative correlation between prices and coupons and the dynamic results suggest that monopoly price discrimination models are not as important as economists might expect and that coupons and price discounts are complements rather than substitutes. We considered evidence bearing on several additional explanations for coupons. The results seem to suggest that strategic interactions between manufacturers are important to understanding coupons, as are the incentives given to the people within firms who make decisions about coupons. We are less optimistic that explanations based on dynamic demand effects or the vertical relationship between cereal manufacturers and retailers are applicable.

The number of coupons issued by all consumer goods manufacturers grew at over ten percent a year between 1980 and 1995. As our data demonstrate, cereal manufacturers contributed to this growth. Recently, however, a number of manufacturers have tried to curtail or completely stop couponing. In 1995, for instance, General Mills announced that it would no longer issue coupons but would instead commit to "every day low prices." The commitment did not last, however, and General Mills resumed issuing coupons. (Note that no other cereal manufacturers followed General Mills in 1995.) In 1996, Procter \& Gamble and nine other consumer products manufacturers stopped issuing coupons in three cities in upstate New York. Consumers met this announcement with revolt, staging boycotts of Procter \& Gamble's products and convincing local politicians to take on the issue. The companies resumed couponing and eventually paid $\$ 4.2$ million to settle charges that they had colluded to agree to stop issuing coupons.

\footnotetext{
${ }^{33}$ Because we are studying the top- 25 cereal brands, many of which have existed since the early 1900 's, we expected a priori that we would find evidence consistent with price discrimination and would not observe brand trial effects.
} 
The fact that manufacturers seem to dislike coupons lends credence to our finding that coupons are not profit-enhancing price discriminatory mechanisms. (Procter $\&$ Gamble's senior vice president for advertising and market research told the Wall Street Journal, "I don't like couponing. Period," Narisetti (1997).) General Mill's claim that they would lower shelf prices when they stopped couponing appears inconsistent with our findings but may either reflect the long-run costs of couponing or may be a public relations gesture more than a description of a new pricing policy. Clearly more work needs to be done to buttress our findings, but preliminary results suggest that coupons are not good examples of monopoly third-degree price discrimination.

There are many possible extensions to our work. Since our results suggest that seller decisions about prices and coupons are inconsistent with the simple textbook view of coupons as price discrimination tools, there is scope for more theoretical work on the rationales for coupons. We have tried to supply as many "stylized facts" as possible to motivate such work. Armed with additional theory one could reexamine our data with a structural model, which could measure the effects of various couponing strategies. 


\section{Data Appendix}

This Appendix contains more details on our data beginning with a description of the coupon data used throughout section 4 , and then describing the city-level variables used in Table 7.

\section{COUPON DATA}

We made several decisions and assumptions in constructing the coupon data set. Here we describe those decisions, and discuss the sensitivity of our results to them.

\section{Percent National}

The coupon data from PIM are organized by brand and, within brands, by the month on which the coupon was dropped. Within a brand-month, there are usually several entries (anywhere from zero to thirty-five), distinguishing coupons dropped by different distributors, dropped on a different day within the month or distributed to different cities. For most entries, the exact cities to which the coupon was distributed are listed. For some, however, the data indicate simply that a coupon was targeted to a certain percent of the national market. For some of these percent national coupons, we can identify the exact cities they were targeting (e.g. because they are distributed to 100 percent of the national market). For most entries listing the percent national, however, we developed an algorithm for assigning the coupons to specific cities. Specifically, if a percent national coupon was listed, we allocated it to all cities that were not individually cited on other entries issued by the same distributor on the same date. We calculated the probability that those cities received a coupon based on the target percent of the national market divided by the percent of the national market for which they accounted. In other words, if 40 percent of the cities received individual coupons and there was a coupon targeted at 20 percent of the national market, we assumed that the remaining 60 percent of the cities received a coupon with probability one-third.

We experimented with a number of different methods for allocating the percent national, and our results are not sensitive to the specific algorithm we use. (Some of the algorithms we considered included assigning percent national coupons with greater than 80 percent coverage to all cities or aligning coupons not only on date and distributor but also on restrictions and cents-off discount.) Also, we checked the coupons in our data set versus the coupons recorded in the free-standing inserts distributed through the local papers in Atlanta and Boston, and found a high level of accuracy. If anything, we attributed more coupons to the cities than were actually distributed, suggesting to us that the mean of COUPON DUMMY in Table 1 is too high. The algorithm we use will overstate the percent of cities with a coupon for a given brand if some of the percent national coupons were allocated to cities that already were getting a coupon from the same distributor on the same day. For instance, Grape Nuts might offer a 50-cent coupon to 80 percent of the national market and a 35-cent coupon in Boston on the same day. Our algorithm assumes that Boston did not get the 50-cent coupon since it was already getting the 35-cent coupon, but it's possible that Boston got two coupons - one for 35 
cents and one for 50 cents. As a result of this attribute of our data, however, we are least confident in results that rely on cross-city comparisons.

\section{Restrictions}

In the results presented, we exclude all coupons that required the consumer either to purchase another product, such as another cereal, or to send in proofs of purchase. We do this because assigning values to most of theses coupons is difficult (e.g. the coupon will guarantee to cover the cost of the purchase of a can of coffee, up to a certain limit). We also have information on PIM's estimates of the direct costs the manufacturer will incur redeeming the coupons. (The estimates are made by PIM using industry accepted redemption rates for certain types of coupons and distribution vehicles.) Based on those estimates, the coupons with restrictions that we exclude are not nearly as widely used as coupons without restrictions. Finally, results obtained including coupons involving restrictions are similar to the ones we present (unless otherwise noted).

\section{Aggregation}

Most studies of coupons use transaction level data and incorporate specific information about the buyer. We have opted to use data with richer cross-sectional and time-series properties, though in order to do that we need to use data that aggregates over transactions along several dimensions. We performed several tests to evaluate the extent to which the aggregation is affecting our results.

Aggregation by Box Size: The SHELF PRICE variable was created by dividing the dollar sales by the number of pounds sold. Cereal is sold in boxes of different sizes (generally between 10 and 20 ounces) and the price per pound varies by box size, tending to lower for larger boxes. If consumers systematically buy cereal in either larger or smaller boxes when coupons are available, the correlation we observe between prices and coupons will reflect this.

There are several reasons to believe that the patterns of box size sales would vary based on the availability of a coupon. For one, coupons may convince consumers to buy a brand that they otherwise would not have (so that their box-size choice will change the average box size) and some coupons only apply to bigger box sizes. We evaluated the extent to which such an effect is influencing our results by excluding coupons that imposed some size restriction on purchases. The results with the smaller subset of coupons were similar to those presented in Table 2. Coupons may also draw consumers who buy larger sizes into the cereal market, if, for instance, consumers with larger households are more likely to change their buying behavior in response to a coupon promotion. It is also conceivable that coupons will induce people to buy smaller boxes since the deduction offered by the coupon represents a larger fraction of the price. In that case, the results in Table 2 would understate the negative correlation between coupons and shelf prices. 
AgGregation OVER A QUARTER: The pricing information we have also represents the average over a quarter. The negative correlation between prices and coupons we report in Table 5 would misstate the true relationship if sellers increased prices for a short time immediately after they issued a coupon and then lowered prices (below the level at which they set them in quarters without coupons) for the rest of the quarter. While somewhat contrived, this behavior would be consistent with the idea that sellers use coupons to price discriminate immediately following the coupon drop and then lower them to encourage coupon users to buy the product again. (This could be rational if consumers form product preferences over time - eventually the seller could raise the price.)

We evaluated the extent to which the aggregation by quarter is affecting our results by developing a variable to measure the number of coupons that were issued in a city for a particular brand during a quarter. We only considered coupons to be distinct if they were issued more than seven days apart. On average if a coupon is issued at all, 1.6 coupons are issued per quarter and the maximum number issued over a quarter is 5 When we included the number of coupons issued over the quarter along with the coupon dummy variable in specifications similar to those in Table 2, the results suggest that a larger number of coupons are associated with lower average prices. That suggests the negative correlation between prices and coupons is contemporaneous.

AgGregation ACrOSS Grocery STORES: Our data also aggregate across grocery stores, though since nearly all grocery stores accept coupons, each store faces the same incentive to change cereal prices in response to coupons. One could imagine that coupons might lead people to shop at more expensive stores, suggesting that the results in Table 2 understate the negative correlation between coupons and prices at a given store. It is hard to believe, however, that customers change their behavior in response to a coupon for one product.

\section{CITY-LEVEL DATA}

Table 7 reports results relating various city-level variables to pricing and couponing by city. The source for all variables, except DOUBLING, was the IRI Infoscan Data Base at the University of Connecticut, Food Marketing Center. We obtained the information to construct DOUBLING in personal correspondence with IRI. Except where noted, we have annual information for all variables between 1989 and 1992. We do not have information about DOUBLING in Shreveport, MS, so we limit the cross-city comparisons to 64 cities. Definitions and summary statistics for the city-level variables are as follows.

\% SUPERMARKETS - measures the percent of food sold through supermarkets, where a supermarket is defined as a full-line, self-service food store with annual volume of $\$ 2$ million or more.

$(64$ - city mean $=.74$, standard deviation $=.04)$

GROCERY CR4 - measures the 4-firm concentration ratio across owners of both grocery stores and supermarkets. 
$(64$ - city mean $=.65$, standard deviation $=.13)$

STORES DOUBLING - measures the percent of sales volume through stores that offer to double and/or triple manufacturers' coupons. For each city, we take the average information over the last three quarters of 1992, the earliest dates for which we have information.

$(64$-city mean $=.42$, standard deviation $=.34)$

NEWSPAPER DUOPOLY - is a dummy variable equal to one if the city is served by more than one Sunday newspaper. We constructed this variable based on the major newspapers tracked by PIM.

$(64$-city mean $=.09$, standard deviation $=.29)$

NUMBER $H H$ - measures the number of households in the city.

$(64$ - city mean $=938,000$, standard deviation $=997,000)$

$\%$ LOW INCOME - measures the percent of households with incomes below $\$ 10,000$ per year.

$(64$ - city mean $=.15$, standard deviation $=.03)$

$\%$ HIGH INCOME - measures the percent of households with incomes above $\$ 50,000$ per year.

$(64$-city mean $=.24$, standard deviation $=.06)$

MEDIAN AGE - measures the median age within the city

$(64$ - city mean $=33.2$, standard deviation $=2.2)$

FAMILY SIZE - measures the median household size

$(64$-city mean $=2.6$, standard deviation $=.13)$

$\%$ HISPANIC - measures the fraction of each city's population that is Hispanic.

$(64$-city mean $=.07$, standard deviation $=.12)$ 


\section{REFERENCES}

Borenstein, Severin. 1985. "Price Discrimination in Free-Entry Markets." RAND Journal of Economics 16 (Autumn): 380-97.

Bowman, Russell D. 1980. Couponing and Rebates, New York: Chain Store Publishing Corp.

Carlton, Dennis W. and Jeffrey M. Perloff. 1994. Modern Industrial Organization. New York: HarperCollins.

Chamberlain, Gary.1983. "Panel Data." In Z. Griliches and M. D. Intrilligator, eds., The Handbook of Econometrics, Volume 2. New York: North-Holland.

Chiang, Jeongwen. 1995. "Competing Coupon Promotions and Category Sales." Marketing Science 14 (Winter): 105-122.

Corts, Kenneth. 1998. "Third-degree Price Discrimination in Oligopoly: All-Out Competition and Strategic Commitment." RAND Journal of Economics 29 (Summer): 306-323.

Eppen, Gary D. and Yehoshua Liebermann. 1984. "Why Do Retailers Deal? An Inventory Explanation.” Journal of Business 57 (October): 519-530.

Gerstner, Eitan, James D. Hess and Duncan M. Holthausen. 1994. "Price Discrimination Through a Distribution Channel: Theory and Evidence." American Economic Review 84 (December): 1437-1445.

Gerstner, Eitan and James D. Hess. 1991. "Who Benefits from Large Rebates: Manufacturer, Retailer or Consumer?" Economics Letters 36 (May): 5-8.

Green, Corliss. 1997. "In-Store versus Out-of-Store Coupons: An Examination of Anglo-, African-, and Hispanic-American Redemption." Journal of Marketing Theory and Practice 5 (Winter): 113-121.

Griliches, Zvi and Jerry Hausman. 1986. "Errors in Variables in Panel Data." Journal of Econometrics 31 (February): 93-118.

Hamilton, James D. 1994. Time Series Analysis. Princeton: Princeton University Press.

Hausman, Jerry. 1978. "Specification Tests in Econometrics." Econometrica 46 (November): 1251-1271.

Holmes, Thomas J. 1989. "The Effects of Third-Degree Price Discrimination in Oligopoly." American Economic Review 79 (March): 244-50.

Holtz-Eakin, Douglas, Whitney Newey, and Harvey S. Rosen. 1988. "Estimating Vector Autoregressions with Panel Data." Econometrica 56 (November): 1371-1395.

Howell, Jamie. 1991. "Potential Profitability and Decreased Consumer Welfare Through Manufacturers' Cents-Off Coupons." The Journal of Consumer Affairs 25 (Summer): 164-184. 
Katz, Michael L. 1984. "Price Discrimination and Monopolistic Competition." Econometrica 52 (November): 1453-1471.

LeClerc, France and John D. C. Little. 1997. "Can Advertising Copy Make FSI Coupons More Effective?” Journal of Marketing Research. 34 (November): 473-484.

Lee, Jonq-Ying and Mark G. Brown. 1985. "Coupon Redemption and the Demand for Frozen Concentrated Orange Juice: A Switching Regression Analysis." American Journal of Agricultural Economics 67 (August): 647-653.

Levedahl, J. William. 1986. "Profit-Maximizing Pricing of Cents-Off Coupons: Promotion or Price Discrimination?" Quarterly Journal of Business and Economics 25 (Fall): 56-70.

Lott Jr., John R. and Russell D. Roberts. 1991. "A Guide to the Pitfalls of Identifying Price Discrimination." Economic Inquiry 29 (January): 14-23.

Narasimhan, Chakravarthi. 1984. "A Price Discrimination Theory of Coupons." Marketing Science 3 (Spring): 128-47.

Narisetti, Raju. 1997. "Upstate New York Test Sparks Boycotts and an Antitrust Probe." Wall Street Journal April 17: a1.

Neslin, Scott A. 1990. "A Market Response Model for Coupon Promotions." Marketing Science 9 (Spring): 125-145.

and Darral G. Clarke. 1987. "Relating the Brand Use Profile of Coupon Redeemers to Brand and Coupon Characteristics." Journal of Advertising Research (February/March): 23-32.

, Caroline Henderson and John Quelch. 1985. "Consumer Promotions and the Acceleration of Product Purchases.” Marketing Science. 4 (Spring): 147-165.

Nevo, Aviv. 1998. "Measuring Market Power in the Ready-to-eat Cereal Industry." NBER Working Paper No. 6387.

Pindyck, Robert and Daniel Rubinfeld. 1995. Microeconomics, 3rd ed. Englewood Cliffs, NJ: Prentice Hall.

Scherer, F.M. 1979. "The Welfare Economics of Product Variety: An Application to the Ready-To-Eat Cereals Industry." The Journal of Industrial Economics 28 (December): 113-134.

Schmalensee, Richard. 1978. "Entry Deterrence in the Ready-to-Eat Breakfast Cereal Industry." Bell Journal of Economics 9 (Autumn): 305-327.

Schmalensee, Richard. 1981. "Output and Welfare Implications of Monopolistic ThirdDegree Price Discrimination." American Economic Review 71 (March): 243-47. 
Sethuraman, Raj and John Mittelstaedt. 1992. "Coupons and Private Labels: A CrossCategory Analysis of Grocery Products." Psychology and Marketing 9 (November/December): 487-500.

Sobel, Joel. 1984. "The Timing of Sales." Review of Economic Studies 51 (July): 353-368.

Srinivasan, Srini S., Robert P. Leone and Francis J. Mulhern. 1995. "The Advertising Exposure Effect of Free Standing Inserts." Journal of Advertising 24 (Spring): 2940.

Varian, Hal R. 1985. "Price Discrimination and Social Welfare." American Economic Review 75 (September): 870-75.

. 1989. "Price Discrimination." In R. Schmalensee and R.D. Willig, eds., Handbook of Industrial Organization, Volume 1, New York: North-Holland.

Vilcassim, Naufel J. and Dick R. Wittink. 1987. "Supporting a Higher Shelf Price Through Coupon Distributions." The Journal of Consumer Marketing 4 (Spring): 29-39.

Wongtrakool, Bonnie. 1994. "An Assessment of the "Cereal Killers": Private Labels in the Ready-to-Eat Cereal Industry." Senior Thesis. Harvard University. 
Table 1: Summary Statistics

\begin{tabular}{|c|c|c|c|c|c|c|}
\hline Description & Mean & Median & Std & $\begin{array}{c}\text { Brand } \\
\text { Variation }\end{array}$ & $\begin{array}{c}\text { City } \\
\text { Variation }\end{array}$ & $\begin{array}{c}\text { Quarter } \\
\text { Variation }\end{array}$ \\
\hline DOLLARS OFF (\$) & .50 & .49 & .22 & $13.1 \%$ & $5.6 \%$ & $6.2 \%$ \\
\hline COUPON DUMMY & .85 & .96 & .30 & $10.7 \%$ & $3.7 \%$ & $4.1 \%$ \\
\hline SHELF PRICE (\$/lb) & 2.97 & 2.94 & .63 & $78.3 \%$ & $7.6 \%$ & $7.4 \%$ \\
\hline
\end{tabular}


Table 2: Estimates of the Relationship between Shelf Price and Coupon Value Dependent Variable is SHELF PRICE

\begin{tabular}{|c|c|c|c|c|}
\hline & \multicolumn{4}{|c|}{ Specification } \\
\hline & I & II & III & IV \\
\hline DOLLARS OFF & $\begin{array}{l}-.009 \\
(.031)\end{array}$ & $\begin{array}{l}-.167 \\
(.034)\end{array}$ & $\begin{array}{l}-.180 \\
(.031)\end{array}$ & $\begin{array}{l}-.065 \\
(.008)\end{array}$ \\
\hline Adj. $R^{2}$ & .0000 & .074 & .148 & .930 \\
\hline COUPON DUMMY & $\begin{array}{l}.098 \\
(.020)\end{array}$ & $\begin{array}{l}.030 \\
(.020)\end{array}$ & $\begin{array}{l}.016 \\
(.017)\end{array}$ & $\begin{array}{l}-.040 \\
(.006)\end{array}$ \\
\hline Adj. $R^{2}$ & .002 & .071 & .144 & .930 \\
\hline $\begin{array}{r}\text { Fixed-Effects } \\
\text { Estimated: }\end{array}$ & None & Quarter & Quarter, City & $\begin{array}{c}\text { Quarter, City, } \\
\text { Brand }\end{array}$ \\
\hline \multirow[t]{3}{*}{ \# Observations } & 23,350 & 23,350 & 23,350 & 23,350 \\
\hline & \multicolumn{4}{|c|}{ Specification } \\
\hline & $\mathrm{V}$ & VI & VII & VIII \\
\hline DOLLARS OFF & $\begin{array}{l}-.050 \\
(.008)\end{array}$ & $\begin{array}{l}-.065 \\
(.014)\end{array}$ & $\begin{array}{l}-.023 \\
(.008)\end{array}$ & $\begin{array}{l}-.001 \\
(.007)\end{array}$ \\
\hline Adj. $R^{2}$ & .954 & .950 & .98 & .99 \\
\hline COUPON DUMMY & $\begin{array}{l}-.037 \\
(.006)\end{array}$ & $\begin{array}{l}-.012 \\
(.010)\end{array}$ & $\begin{array}{l}-.007 \\
(.006)\end{array}$ & $\begin{array}{l}.0001 \\
(.005)\end{array}$ \\
\hline Adj. $R^{2}$ & .954 & .950 & .98 & .99 \\
\hline $\begin{array}{l}\text { Fixed-Effects } \\
\text { Estimated: }\end{array}$ & $\begin{array}{l}\text { City-Brand, } \\
\text { Quarter }\end{array}$ & $\begin{array}{c}\text { Brand-Quarter, } \\
\text { City }\end{array}$ & $\begin{array}{l}\text { City-Brand, } \\
\text { Brand-Quarter }\end{array}$ & $\begin{array}{l}\text { City-Brand, } \\
\text { Brand-Quarter, } \\
\text { City-Quarter }\end{array}$ \\
\hline \# Observations & 23,350 & 23,350 & 23,350 & 23,350 \\
\hline
\end{tabular}

Note: Standard errors are in parentheses. They are robust to the presence of heteroskedasticity and adjust for correlation in the errors within a brand of cereal in a particular city. 
Table 3: Number of Coupon Issues by Segment and Manufacturer

\begin{tabular}{lccccccc}
\hline Type & Kellogg & $\begin{array}{c}\text { General } \\
\text { Mills }\end{array}$ & Post & $\begin{array}{c}\text { Quaker } \\
\text { Oats }\end{array}$ & $\begin{array}{c}\text { Nabisc } \\
\text { o }\end{array}$ & Total & $\begin{array}{c}\text { Total per } \\
\text { Brand }\end{array}$ \\
\hline All FamilylBasic & 5,203 & 4,699 & 0 & 0 & 0 & 9,902 & 1,980 \\
Kids & $(3)$ & $(2)$ & & & & $(5)$ & \\
& 5,568 & 8,035 & 0 & 2,673 & 0 & 16,276 & 1,628 \\
Simple Health/ Nutrition & $(3)$ & $(5)$ & & $(2)$ & & $(10)$ & \\
Taste Enhanced & 1,551 & 2,551 & 1,750 & 0 & 1,055 & 6,907 & 1,727 \\
Wholesome & $(1)$ & $(1)$ & $(1)$ & & $(1)$ & $(4)$ & \\
& 3,634 & 2,050 & 3,077 & 1,576 & 0 & 10,337 & 1,723 \\
& $(2)$ & $(1)$ & $(2)$ & $(1)$ & & $(6)$ & \\
Total & & & & & & & \\
Total per brand & 15,956 & 17,335 & 4,827 & 4,249 & 1,055 & & \\
& $(9)$ & $(9)$ & $(3)$ & $(3)$ & $(1)$ & 43,422 & \\
\hline
\end{tabular}

Note: This table lists the number of coupons issued by company by segment. Coupons issued by the same distributor on the same day but in different cities are counted as separate coupons, as are coupons issued during the same quarter in the same city, but on different days or by different distributors. The number of brands per cell is listed in parentheses.

Table 4: Number of Coupon Issues by Quarter

\begin{tabular}{rrrrrr}
\hline & Q1 & Q2 & Q3 & Q4 & Total \\
\hline 1989 & 2,268 & 2,298 & 2,194 & 1,667 & 8,427 \\
1990 & 2,768 & 2,096 & 2,415 & 2,369 & 9,648 \\
1991 & 2,859 & 2,473 & 2,794 & 3,749 & 11,875 \\
1992 & 3,488 & 3,476 & 3,204 & 3,304 & 13,472 \\
& & & & & \\
Total & 13,095 & 11,601 & 10,607 & 11,089 & 43,422 \\
\hline
\end{tabular}

Note: This table lists the number of coupons issued by quarter. The definition of a single coupon is explained in the notes to Table 3 . 
Table 5: The Relationship between Shelf Price and Coupon Value in the Presence of Competitors' Coupons

Dependent Variable is SHELF PRICE

\begin{tabular}{|c|c|c|c|c|}
\hline & \multicolumn{4}{|c|}{ Specification } \\
\hline & I & II & III & IV \\
\hline COUPON DUMMY & $\begin{array}{l}.110 \\
(.070)\end{array}$ & $\begin{array}{l}-.014 \\
(.084)\end{array}$ & $\begin{array}{l}-.118 \\
(.065)\end{array}$ & $\begin{array}{l}.072 \\
(.017)\end{array}$ \\
\hline COMPETITORS' COUPON & $\begin{array}{l}-.224 \\
(.074)\end{array}$ & $\begin{array}{l}-.507 \\
(.098)\end{array}$ & $\begin{array}{l}-.667 \\
(.075)\end{array}$ & $\begin{array}{l}.085 \\
(.019)\end{array}$ \\
\hline $\begin{array}{r}\text { COUPON DUMMY * } \\
\text { COMPETITORS' COUPON }\end{array}$ & $\begin{array}{l}-.003 \\
(.078)\end{array}$ & $\begin{array}{l}.051 \\
(.093)\end{array}$ & $\begin{array}{l}.136 \\
(.077)\end{array}$ & $\begin{array}{l}-.138 \\
(.021)\end{array}$ \\
\hline $\mathrm{R}^{2}$ & .007 & .087 & .167 & .931 \\
\hline Fixed-Effects Estimated: & None & Quarter & Quarter, City & $\begin{array}{l}\text { Quarter, City, } \\
\text { Brand }\end{array}$ \\
\hline \multirow[t]{3}{*}{ \# Observations } & 23,350 & 23,350 & 23,350 & 23,350 \\
\hline & \multicolumn{4}{|c|}{ Specification } \\
\hline & $\mathrm{V}$ & VI & VII & VIII \\
\hline COUPON DUMMY & $\begin{array}{l}.064 \\
(.017)\end{array}$ & $\begin{array}{l}.068 \\
(.023)\end{array}$ & $\begin{array}{l}.012 \\
(.009)\end{array}$ & $\begin{array}{l}-.001 \\
(.008)\end{array}$ \\
\hline COMPETITORS' COUPON & $\begin{array}{l}.071 \\
(.020)\end{array}$ & $\begin{array}{l}.059 \\
(.025)\end{array}$ & $\begin{array}{l}-.004 \\
(.016)\end{array}$ & $\begin{array}{l}-.007 \\
(.012)\end{array}$ \\
\hline $\begin{array}{r}\text { COUPON DUMMY * } \\
\text { COMPETITORS' COUPON }\end{array}$ & $\begin{array}{l}-.123 \\
(.021)\end{array}$ & $\begin{array}{l}-.099 \\
(.025)\end{array}$ & $\begin{array}{l}-.041 \\
(.013)\end{array}$ & $\begin{array}{l}-.0003 \\
(.012)\end{array}$ \\
\hline $\mathrm{R}^{2}$ & .958 & .951 & .98 & .99 \\
\hline Fixed-Effects Estimated: & $\begin{array}{l}\text { Brand*City, } \\
\text { Quarter }\end{array}$ & $\begin{array}{c}\text { Brand*Quarter, } \\
\text { City }\end{array}$ & $\begin{array}{l}\text { Brand*City, } \\
\text { Brand*Quarter }\end{array}$ & $\begin{array}{l}\text { Brand*City, } \\
\text { Brand*Quarter, } \\
\text { City*Quarter }\end{array}$ \\
\hline \# Observations & 23,350 & 23,350 & 23,350 & 23,350 \\
\hline
\end{tabular}


Table 6: Coupon Issues for Select Cities

\begin{tabular}{lccc}
\hline \multicolumn{1}{c}{ City } & \# of issues & $\begin{array}{c}\text { Average Discount } \\
(\$)\end{array}$ & $\begin{array}{c}\text { Total discount }(\$) \\
\text { per quarter }\end{array}$ \\
\hline Boston & 504 & .50 & 15.87 \\
Little Rock & 589 & .57 & 20.94 \\
Albany & 598 & .59 & 21.86 \\
Columbus & 612 & .58 & 22.11 \\
San Francisco & 645 & .60 & 24.23 \\
Los Angeles & 673 & .42 & 17.83 \\
Denver & 726 & .63 & 28.45 \\
Dallas & 785 & .70 & 34.32 \\
& & & 23.18 \\
65-city AVERAGE & 630 & .59 & 3.30 \\
\multicolumn{2}{c}{ STANDARD } \\
DEVIATION
\end{tabular}

Note: Column I lists the total number of coupons issued during a quarter in several cities. The definition of a single coupon is explained in the notes to Table 3 . Columns II and III list, respectively, the average discount on the typical coupon in each city, and the total discount per quarter for each city. 
Table 7: Cross-City Coupon and Price Patterns

\begin{tabular}{|c|c|c|c|c|}
\hline \multirow[t]{2}{*}{ Dependent Variable: } & \multirow{2}{*}{$\begin{array}{c}C O U P O N \\
D U M M Y \\
\mathrm{I}\end{array}$} & \multicolumn{2}{|c|}{$\begin{array}{l}\text { COUPON DUMMY } \\
\text { (including restricted) }\end{array}$} & \multirow{2}{*}{$\begin{array}{c}\text { PRICE } \\
\text { IV }\end{array}$} \\
\hline & & II & III & \\
\hline \multirow[t]{2}{*}{$\%$ SUPERMARKETS } & -.733 & .018 & -.020 & 1.19 \\
\hline & $(.451)$ & $(.059)$ & $(.061)$ & $(.82)$ \\
\hline \multirow[t]{2}{*}{ GROCERY CR4 } & .026 & -.011 & -.011 & -.139 \\
\hline & $(.034)$ & $(.011)$ & $(.014)$ & $(.161)$ \\
\hline \multirow[t]{2}{*}{ STORES DOUBLING } & -.011 & .011 & .009 & .142 \\
\hline & $(.018)$ & $(.005)$ & $(.006)$ & $(.072)$ \\
\hline \multirow[t]{2}{*}{ NEWSPAPER DUOPOLY } & -.033 & .011 & .009 & .037 \\
\hline & $(.027)$ & $(.006)$ & $(.007)$ & $(.108)$ \\
\hline \multirow[t]{2}{*}{$\ln (N U M B E R H H)$} & .043 & .007 & .008 & -.064 \\
\hline & $(.021)$ & $(.004)$ & $(.005)$ & $(.100)$ \\
\hline \multirow[t]{2}{*}{$\%$ LOW INCOME } & -.083 & -.179 & -.192 & 2.41 \\
\hline & $(.438)$ & $(.088)$ & $(.106)$ & $(1.61)$ \\
\hline \multirow[t]{2}{*}{$\%$ HIGH INCOME } & -.235 & -.063 & -.050 & 1.95 \\
\hline & $(.263)$ & $(.058)$ & $(.066)$ & $(1.03)$ \\
\hline \multirow[t]{2}{*}{$M E D I A N A G E$} & -.002 & -.002 & -.002 & .011 \\
\hline & $(.006)$ & $(.001)$ & $(.002)$ & $(.031)$ \\
\hline \multirow[t]{2}{*}{ FAMILY SIZE } & -.085 & -.019 & -.024 & -.149 \\
\hline & $(.074)$ & $(.023)$ & $(.027)$ & $(.448)$ \\
\hline \multirow[t]{2}{*}{$\%$ HISPANIC } & .036 & .008 & -.024 & .273 \\
\hline & $(.050)$ & $(.019)$ & $(.027)$ & (.269) \\
\hline $\mathrm{R}^{2}$ & .48 & .55 & .58 & .42 \\
\hline \# Observations & 64 & 64 & 51 & 51 \\
\hline
\end{tabular}

Note: This table reports coefficients from OLS estimates. All estimates include dummy variables for six geographic regions (the seventh is omitted). Robust standard errors are in parentheses. 
Table 8: VAR Estimates of the Dynamics of Coupon Existence, Shelf Price, and Volume

\begin{tabular}{|c|c|c|c|c|c|c|}
\hline & $\mathrm{I}$ & II & III & IV & $\overline{\mathrm{V}}$ & VI \\
\hline Dependent Variable & $\begin{array}{c}C O U P O N \\
D U M M Y_{t}\end{array}$ & $\begin{array}{l}\text { SHELF } \\
\text { PRICE }_{t}\end{array}$ & $V O L U M E_{t}$ & $\begin{array}{l}\text { COUPON } \\
\text { DUMMY }_{t}\end{array}$ & $\begin{array}{l}\text { SHELF } \\
\text { PRICE }_{t}\end{array}$ & VOLUME \\
\hline COUPON DUMMY $Y_{t-1}$ & $\begin{array}{l}-.025 \\
(.040)\end{array}$ & $\begin{array}{l}-.019 \\
(.015)\end{array}$ & $\begin{array}{c}.011 * * * \\
(.003)\end{array}$ & $\begin{array}{l}.159 * * * \\
(.010)\end{array}$ & $\begin{array}{c}-.018 * * * \\
(.003)\end{array}$ & $\begin{array}{l}-.000 \\
(.001)\end{array}$ \\
\hline COUPON DUMMY $Y_{t-2}$ & $\begin{array}{c}.126 * * * \\
(.030)\end{array}$ & $\begin{array}{l}-.019 * \\
(.011)\end{array}$ & $\begin{array}{c}.007 * * * \\
(.002)\end{array}$ & $\begin{array}{c}.249 * * * \\
(.011)\end{array}$ & $\begin{array}{l}-.002 \\
(.003)\end{array}$ & $\begin{array}{l}-.001 \\
(.001)\end{array}$ \\
\hline COUPON DUMMY $Y_{t-3}$ & $\begin{array}{l}-.023 \\
(.017)\end{array}$ & $\begin{array}{c}-.029 * * * \\
(.007)\end{array}$ & $\begin{array}{c}.005 * * * \\
(.001)\end{array}$ & $\begin{array}{l}.016 * * \\
.008)\end{array}$ & $\begin{array}{c}-.009 * * * \\
(.003)\end{array}$ & $\begin{array}{c}-.003 * * * \\
(.001)\end{array}$ \\
\hline COUPON DUMMY $Y_{t-4}$ & $\begin{array}{c}.047 * * * \\
(.012)\end{array}$ & $\begin{array}{c}-.023 * * * \\
(.005)\end{array}$ & $\begin{array}{c}.006 * * * \\
(.001)\end{array}$ & $\begin{array}{l}.078 * * * \\
(.009)\end{array}$ & $\begin{array}{c}-.009 * * * \\
(.003)\end{array}$ & $\begin{array}{c}.001 \\
(.001)\end{array}$ \\
\hline SHELF PRICE $E_{t-1}$ & $\begin{array}{l}-.080 \\
(.224)\end{array}$ & $\begin{array}{c}.470 * * * \\
(.121)\end{array}$ & $\begin{array}{l}.055 * * \\
(.028)\end{array}$ & $\begin{array}{c}.084 * * * \\
(.018)\end{array}$ & $\begin{array}{c}.667 * * * \\
(.013)\end{array}$ & $\begin{array}{c}.010 * * * \\
(.003)\end{array}$ \\
\hline SHELF PRICE $E_{t-2}$ & $\begin{array}{c}-.225 * * * \\
(.078)\end{array}$ & $\begin{array}{c}.167 * * * \\
(.043)\end{array}$ & $\begin{array}{l}.020 * * \\
(.010)\end{array}$ & $\begin{array}{c}-.086 * * * \\
(.019)\end{array}$ & $\begin{array}{c}.237 * * * \\
(.016)\end{array}$ & $\begin{array}{c}.004 \\
(.003)\end{array}$ \\
\hline SHELF PRICE $E_{t-3}$ & $\begin{array}{c}-.123 * * * \\
(.031)\end{array}$ & $\begin{array}{c}-.065 * * * \\
(.018)\end{array}$ & $\begin{array}{c}.014 * * * \\
(.004)\end{array}$ & $\begin{array}{c}-.056 * * * \\
(.022)\end{array}$ & $\begin{array}{c}-.038 * * * \\
(.015)\end{array}$ & $\begin{array}{c}-.008 * * \\
(.004)\end{array}$ \\
\hline SHELF PRICE $E_{t-4}$ & $\begin{array}{c}-.119 * * * \\
(.032)\end{array}$ & $\begin{array}{c}.158 * * * \\
(.020)\end{array}$ & $\begin{array}{c}.013 * * * \\
(.004)\end{array}$ & $\begin{array}{c}.072 * * * \\
(.019)\end{array}$ & $\begin{array}{c}.144 * * * \\
(.012)\end{array}$ & $\begin{array}{l}-.006^{*} \\
(.003)\end{array}$ \\
\hline VOLUME $E_{t-1}$ & $\begin{array}{l}.259 \\
(.448)\end{array}$ & $\begin{array}{l}.222 \\
(.225)\end{array}$ & $\begin{array}{l}-.129 \\
(.191)\end{array}$ & $\begin{array}{c}.003 \\
(.060)\end{array}$ & $\begin{array}{c}.282 * * * \\
(.036)\end{array}$ & $\begin{array}{c}.402 * * * \\
(.030)\end{array}$ \\
\hline$V O L U M E_{t-2}$ & $\begin{array}{l}.174 \\
(.243)\end{array}$ & $\begin{array}{l}-.157 \\
(.123)\end{array}$ & $\begin{array}{l}-.078 \\
(.140)\end{array}$ & $\begin{array}{c}.089 \\
(.071)\end{array}$ & $\begin{array}{c}-.086 * * \\
(.036)\end{array}$ & $\begin{array}{c}.256 * * * \\
(.033)\end{array}$ \\
\hline$V O L U M E_{t-3}$ & $\begin{array}{c}.056 \\
(.147)\end{array}$ & $\begin{array}{c}.003 \\
(.077)\end{array}$ & $\begin{array}{l}-.159 \\
(.100)\end{array}$ & $\begin{array}{c}-.133 * * \\
(.062)\end{array}$ & $\begin{array}{c}.039 \\
(.036)\end{array}$ & $\begin{array}{c}.021 \\
(.034)\end{array}$ \\
\hline$V O L U M E_{t-4}$ & $\begin{array}{c}.078 \\
(.132)\end{array}$ & $\begin{array}{l}-.101 \\
(.067)\end{array}$ & $\begin{array}{l}.172 * * \\
(.084)\end{array}$ & $\begin{array}{c}.040 \\
(.065)\end{array}$ & $\begin{array}{c}-.266 * * * \\
(.037)\end{array}$ & $\begin{array}{c}.342 * * * \\
(.037)\end{array}$ \\
\hline $\begin{array}{l}\text { Fixed-Effects } \\
\text { Estimated: }\end{array}$ & $\begin{array}{c}\text { City-brand } \\
\text { Quarter }\end{array}$ & $\begin{array}{c}\text { City-brand } \\
\text { Quarter }\end{array}$ & $\begin{array}{c}\text { City-brand } \\
\text { Quarter }\end{array}$ & -- & -- & -- \\
\hline $\begin{array}{r}\text { Variance-Covaria } \\
\text { COUPON DUMMY } \\
\text { SHELF PRICE } \\
\text { VOLUME }\end{array}$ & $\begin{array}{c}\text { ance of Resid } \\
.0899 \\
-.0040 \\
.0012\end{array}$ & $\begin{array}{l}.0215 \\
-.0010\end{array}$ & .0011 & $\begin{array}{l}.0574 \\
-.0009 \\
.00005\end{array}$ & $\begin{array}{l}.0133 \\
-.0010\end{array}$ & .0011 \\
\hline $\begin{array}{r}\mathrm{R}^{2} \\
\text { \# Obs }\end{array}$ & $\begin{array}{c}-- \\
15,375\end{array}$ & $\begin{array}{c}-- \\
15,375\end{array}$ & $\begin{array}{c}-- \\
15,375\end{array}$ & $\begin{array}{c}.17 \\
16,850\end{array}$ & $\begin{array}{c}.97 \\
16,850\end{array}$ & $\begin{array}{c}.98 \\
16,850\end{array}$ \\
\hline
\end{tabular}

Note: Asymptotic robust standard errors are in parentheses.

$*$ significant at the $10 \%$ level; ** significant at the $5 \%$ level; *** significant at the $1 \%$ level. 
Figure 1: Impulse-Response Functions of the Dynamics of Coupon Existence, Shelf Price, and Volume
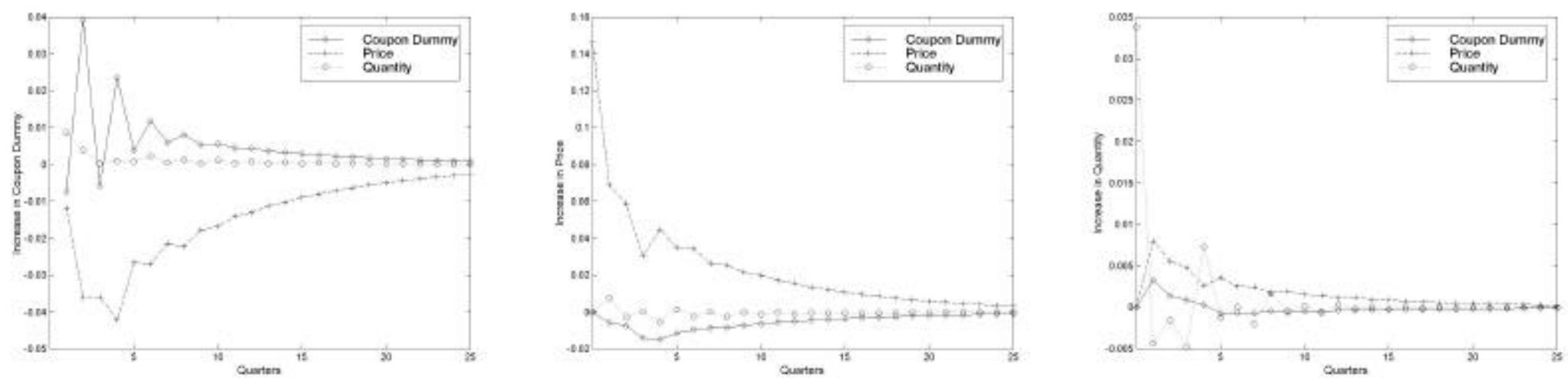


\section{Table A1: Brands Used in Analysis}

\begin{tabular}{llll}
\hline \multicolumn{1}{c}{$\begin{array}{c}\text { All Family/ } \\
\text { Basic Segment }\end{array}$} & \multicolumn{1}{c}{$\begin{array}{c}\text { Taste Enhanced } \\
\text { Wholesome Segment }\end{array}$} & $\begin{array}{c}\text { Simple Health } \\
\text { Nutrition Segment }\end{array}$ & \multicolumn{1}{c}{ Kids Segment } \\
\hline K Corn Flakes & K Frosted Mini Wheats & K Special K & K Corn Pops \\
K Crispix & K Raisin Bran & GM Total & K Froot Loops \\
K Rice Krispies & GM Raisin Nut & P Grape Nuts & K Frosted Flakes \\
GM Cheerios & P Honey Bunches of Oats & N Shredded Wheat & GM Cinn Toast Crunch \\
GM Wheaties & P Raisin Bran & & GM Honey Nut Cheerios \\
& Q 100\% Natural & & GM Kix \\
& & & GM Lucky Charms \\
& & & GM Trix \\
& & & Q CapN Crunch \\
& & Q Life \\
\hline
\end{tabular}

Note: $\mathrm{K}=$ Kellogg's, GM = General Mills, $\mathrm{P}=$ Post, $\mathrm{Q}=$ Quaker and $\mathrm{N}=$ Nabisco. 